\begin{tabular}{r}
\hline \hline $81: 39(=163.41)$ \\
$398(=163.41)$ \\
$811.163 .41 ' 373.46: 393$ \\
https://doi.org $/ 10.18485 / \mathrm{msc} .2017 .46 .3 . c h 4$
\end{tabular}

\author{
Снежана П. ВУЧКОВИЋ* \\ Филолошки факултет \\ Универзитета у Београду
}

\title{
ТАБУ У ЛЕКСИЦИ ПОГРЕБНОГ ОБРЕДА СРПСКОГ ЈЕЗИКА
}

\begin{abstract}
У раду се анализира лексика која припада семантичком пољу погребног обреда. Врши се њена мотивациона реконструкција у настојању да се открију основни номинациони обрасци у оквиру којих је текао процес њеног формалног и значењског уобличења. Осветљава се улога табуа у процесу метафоричне концептуализације те лексике и представљају неки архаични етнокултурни садржаји који су у тим називима нашли свој језички одраз.
\end{abstract}

Кључне речи: лексика погребног обреда, мотивациона реконструкција, табу, метафорична концептуализација, етнолингвистика/лингвокултурологија

1.1. Погребни обред древних Словена био је и пре примања хришћанства веома сложен ритуал. На њега је пресудно утицало древно индоевропско наслеђе, али и контакти Словена са другим народима. Како показују историографски извори и археолошки подаци, распрострањен начин погребног поступања са покојником било је код старих Словена спаљивање, али се у неким културама среће и инхумација. Хришћанство је у ову област увело известан поредак обредом сахрањивања покојника на заједничким гробљима, у гробовима који се освештавају, дајући неким претхришћанским елементима погребног ритуала хришћанску симболику. Древна традиција спаљивања покојника очувала се у словенским земљама све до XII/XIII века. ${ }^{1}$

Погребни обред, као један веома устаљен и донекле затворен систем, поседује сопствену функционално-семантичку структуру и богат је извор реликата словенске старине. Обредна терминологија тј. лексика која се односи

*snezanabaukvuckovic@gmail.com

${ }^{1}$ В. Топоров 1987: 28-30. 
на поједине његове аспекте, истовремено чини и део система датог језика и део културе у којој се обред формирао, те је стога везана и за друге елементе који припадају семиотичком језику културе датог обреда: акционалне (ритуалне радње), предметне (ритуални предмети), персоналне (личности као агенси или објекти ритуалне радње), просторне, временске и сл. Зато је за реконструкцију првобитне мотивације и семантичке еволуције ове лексике веома важна реконструкција етнокултурног контекста у којем се погребни обред формира и функционише тј. њена интерпретација у обзорју духовне културе Словена.

Лексичко-семантичком пољу погребног обредног комплекса припада релативно мали број лексема (на пример у поређењу са лексиком свадбеног или бројних жртвених обреда). Оне су, по правилу, врло архаичне, а одликују се и недовољно прозирним мотивационим везама. На скроман обим овог семантичког поља, као и на прекид мотивационих веза лексема које га чине, пресудно је утицао један екстралингвистички моменат: табуизирање основних појмова везаних са смрћу. Појава табуа у овој лексичкој групи је - као и код других лексичко-семантичких група подложних табуизацији (имена људи, божанских и демонских бића, владара, умрлих, сродника, називи болести и смрти, називи неких животиња и сл.) - била везана за архаичне религиозномитолошке представе о вези између неког предмета или појаве и њиховог назива, што је водило поистовећивању денотата и његовог имена. Одавде је проистекла вера у магијску моћ речи, односно у реч као оружје магијског дејства, те даља забрана употребе оних речи које су могле негативно утицати на човека.

Формирана у контексту табуа, на раним стадијумима развитка култуpe, погребна обредна лексика има поглавито супституциони, еуфемистички карактер. Основни принцип њене номинације је метафора тј. метафоричка концептуализација лексема које се односе на појам смрти, а која има исту идејну основу као и сам табу. То је, заправо, била идеја „скривања”, која стоји у основи семантичког развитка многих од разматраних лексема. Метафорички концептуализован механизам преноса значења у многим се случајевима показује као непрозиран, јер се односи на сферу архаичних есхатолошких представа у којима је скривена његова митолошка основа (в. Седакова 2004: 23).

1.2. Истраживање терминологије погребног обреда тј. анализа семантике и етимологије речи које у ово лексичко-семантичко поље спадају, нису сисематичније проучавани у српској историјској лексикологији. У овом раду ми желимо представити неке од кључних појмова словенског погребног обреда, односно лексема којима се они изражавају, у настојању да реконструишемо њихову примарну мотивацију и откријемо узроке, начине и путеве развитка њиховог значења до данас посведочених облика у српском језику, осветљавајући, притом, улогу табуа у процесу номинације ове лексике. Етнолингвистички приступ датој анализи - који не укључује само језички материјал српског језика и дијалеката, него и фолклорне, етнографске, историографске, археолошке и др. изворе, те поређење са погребном обредном лексиком других словенских језика - омогућава не само реконструкцију првобитне моти- 
вације разматраних лексема, већ и представљање древне слике словенског света која је у тим називима нашла свој језички одраз.

\section{II}

2. 1. У старословенским канонским споменицима појам „СМРТ” (стсл. съ.ирь тъъ) изражава се лексемама чије значење упућује на то да је смрт пре свега схватана као крај живота на земљи: коньць, кончнна, съконьчаннє (СС: 289-290). Верујући у бесмртност душе (пондҺте отъ съмрьтн въ животь в ъчнъ СС: 217), средњовековни човек је веровао да смрт представља премештање, пренос душе у други свет (упор. прьставлюнню СС: 551), вечни сан $^{2}$ (оүсъпєннє СС: 749). У овим лексемама одражена је идеја превладавања чињенице смрти и њеног поимања у опозицији са самим животом: са његовим завршетком (упор. отнтн прен. „умрети” СС: 424), крајем земљског труда и течења (упор. покон прен. „смрт” СС: 470), предајом душе натраг Богу (упор. прЊдатн доүшж „умрети” СС: 200). Наведени примери показују како се метафорична концептуализација табуисаног појма смрти одвијала у контексту њеног хришћанског поимања. ${ }^{3}$

Појам „УМИРАњА” (упор. стсл. миьтн, лат. mors, -tis, лит. mirtis, стинд. m!ti-, од праие. *mr-tei-) у српском језику такође је табуиран, а његов основни лексички израз често супституисан метафоричним лексемама или фразеологизмима као што су скончати, преставити се, упокојити се, уснути, отићи (Богу на истину), предати душу Богу, склопити очи итд. Табуисању је подложно и само називање умрлог, који се означава лексемама које имају еуфемистички, емоционално-експресивни или профилактички карактер: веселник, добросрећник (замена табуисане речи еуфемистичном на основу антонимије), сиромах, тамо он и сл. Међутим, и сама лексема смрт је према неким етимолошким тумачењима еуфемизирана већ у примарном акту своје номинације. Следећи Махекову интерпретацију, Александар Лома претпоставља да префикс $s ъ-$ уноси у основно значење лексеме семантику нечег што је „добро, повољно”. Махеково тумачење се позивало „...на представу о 'својој' - тј. природној у опреци према превременој, насилној - као о 'доброј смрти', одражену у изразима попут рус. умреть своей смертью, лит. sãvo smerčiù mirti, нем. seinen Tod sterben, франц. mourir de sa bonne mort итд. Уопштавање ове изворне семантике на све врсте смрти објашњавало би се еуфемистичком применом речи.” Лома ово Махеково тумачење унеколико модификује закључком који се позива на етимолошко тумачење

\footnotetext{
${ }^{2}$ Представа о смрти као сну кореспондира са погребним обичајем бдењ $а$ над „уснулим’ покојником.

${ }^{3}$ Језик хришћанских светих списа изразито је метафоричан и представља најлепши одраз велике метафоре Логоса тј. Христовог сопственог вербалног откривења. Учење Исуса Христа, онако како је дато у јеванђељима, у великој мери се ослања на метафору, која није само оруђе библијског стила, већ и нека врста хеуристичког средства помоћу којег откривамо бит често табуираних, сакралних појмова хришћанске вере.
} 
везе између праие. основе *su- „добар” и индоиран. именичке основе $a s u$ lahu- „постојање, егзистенција” која се односи како на овоземљаску, тако и на оноземаљску, вишу егзистенцију после смрти: „...оно што смрт дефинише као 'добру' није освртање уназад, на протекли земаљски живот просуђен као 'добро' окончан ако није насилно и превремено прекинут, него поглед унапред, у блажену егзистенцију после смрти као врхунско добро..." (Лома 2004: 59-61). У свом раду посвећеном концепту „ЛОШЕ СМРТИ” Марија Вучковић показује да је и овај концепт, онако како га одражавају различите словенске лексеме, био у основи заснован у сфери културно-семантичких и вредносних опозиција горе / доле, односно прав / крив, савијен, искривљен. Ауторка утврђује да је он у својој вербалној реализацији доминантно метафорички модификован и везан за семантичку сферу псл. глагола *gybnoti (упор. апофонијску варијанту тј. корен $* g ъ b-$ присутан у срп. сагнути се, нагнути се и сл.). Деривати овог глагола (упор. срп. гинути, угинути, погинути) су деетимологизовани јер табуом мотивисана метафора која се налази у основи њихове номинације крије у себи архаизован митолошки елеменат: „Концепт савијања присутан је, на пример, у веровању Словенима блиских паганских Балта да је повијање дима приликом кремације лош знак за посмртну судбину душе, док је усправно кретање дима указивало на то да је душа спасена." (Вучковић 2014: 515).

2.2. Значење „сахранити (труп, тело, остатке покојника)” обележено је у словенским језицима лексемама којима су у основи псл. глаголи *greti, grebo, *horniti, *hovati, *kopati.

Старословенски канонски споменици појам „САХРАНИТИ” изражавају

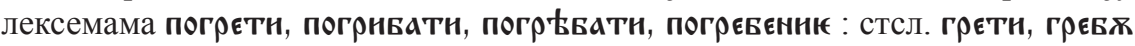
„Грабити, веслати” СС: 178. Ова лексема и њени деривати широко су распрострањени у словенским језицима (упор. срп. гроб, гробље, погреб; буг. погреба; мак. погребе; слов. pogreb, pogrebščina; рус. гроб (примарно је могила), гробовище „гробље” (примарно је кладбщще), цсл. погребать, погребение; чеш. pohřeb; слов. pohreb итд.).

Текстови сакралних старословенских споменика бележе и лексему съхраннтн, али у значењу „сачувати, спасити, сакрити” СС: 674-675 (: Хранитн „чувати, штитити, скривати” СС: 765). Семантички развитак ове лексеме текао је од примарног псл. *horniti sę (: псл. *horna) „хранити, крмити, питати” $\Rightarrow$ „чувати, пазити, скривати” (упор. срп. фразеологизам хранити гују у њедрима). У овим значењима глагол је познат свим словенским језицима. Као термин погребног обреда он није забележен у старословенским споменицима, али је распрострањен у јужнословенским и источнословенским језицима где стоји у различитим односима конкуренције са њему синонимним глаголима (упор. срп. сахранити, сахрана, сахрањивати „укопати покојника" и рус. хоронить, похороны - где је то основни термин; у буг. и мак. су доминантни деривати глагола *greti и *kopati (упор. буг. закоnaя, мак.

\footnotetext{
${ }^{4}$ Семантички паралелизам присутан је у развитку значења синонимне лексеме питати 1. „питати, хранити, крмити”: $\Rightarrow 2$. „одгојити, васпитати” жнв'ашє въ чнстот'В. пнтал д

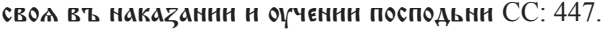


закоna); у словеначком је основни глагол *kopati, али је присутно и *greti; у блр. и укр. је познат, али претеже употреба глагола *hovati, ЭССЯ 8: 78-79).

Културно конотирани секундарни пренос значења глагола *horniti „сачувати, штитити, сакрити” $\Rightarrow$ „сахранити (труп, тело покојника)” могао је одражавати старе претхришћанске представе о загробном животу који подразумева не само вечни живот душе, него и тела покојника (потврду налазимо у археолошкој евиденцији: стављање у гробницу личних предмета, накита, оружја, у словенској старини и бојних коња, робова и жена и др.). Њему синониман глагол *hovati - чије је примарно значење било „крити, сакривати” и у чијем се секундарном значењу „сахранити (покојника)” чува исти семантички пренос значења као и код глагола *horniti - карактеристичан је за неке севернословенске језике (упор. укр. ховати, блр. хаваць, рус. дијал. noховать, чеш. pochovati, стсловач. chowat', пољ. chovać). Светлана Толстој у раду посвећеном семантичкој реконструкцији словенске погребне лексике претпоставља два могућа полазишта за еволуцију значења ове лексеме: а) развитак од примарног значења „крити, сакрити” био је у вези са словенским традиционалним представама о укопу као начину да се покојник тј. смрт уклони из света живих; б) ауторка допушта и могућност везе са „чувањем” тела покојника за његов онострани живот (Толстој С. 2009: 342-347).

Код глагола *kopati (упор. срп. укоn), као и код глагола *greti, *pogreti, значење „сахранити” је секундарно, али мотивационо прозирно. Међутим, и код ових лексема срећемо одраз истог супституционог, еуфемистичког отклона од појма смрти, па се зато идеја „скривања” чињенице смрти своди на конкретне радње поступања са покојником којима се он „склања” из света живих.

Први словенски писани споменици бележе и лексему съжєци „спалити, сажећи" СС: 649, али у контекстима који се доминантно односе на спаљивање тј. уништавање паганских светилишта (капнщє, трьвнщє), идола (капъ, ндокъ, коумннъъ) и њихових верника: упор.: вьса капншта

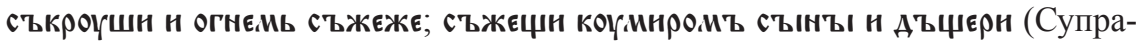
саљски зборник 220: 27; 127: 8) Јеванђеља, пак, ову лексему бележе само у значењу спаљивања предмета (пшенице, плеве и сл.), а ако се ова радња односила на људе, онда је то била казнена мера. Супрасаљски зборник у једном примеру, међутим, бележи и спаљивање светих моштију (упор. съжєгошА

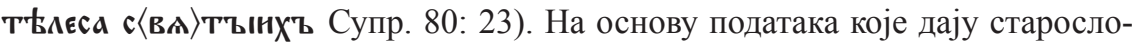
венски канонски текстови можемо рећи да је значење „сажећи, спалити, кремирати (покојника)" на старословенском нивоу претрпело специјализацију везивањем за специфичне употребне контексте (спаљивање паганских светилишта), јер је рано хришћанство овај обред санкционисало као остатак језичества тј. паганства.

О овом старом виду погребне праксе нема у старим српским писаним споменицима директних спомена, што може бити у вези и са екстралингвистички условљеним моментом њеног табуирања под утицајем преовлађујућег модела инхумације који је заступало хришћанство. Међутим, он се наводи у једном члану Душановог законика који сведочи о томе да је традиција спаљи- 
вања тела мртвих, иако санкционисана, постојала и у XIV веку: н мюдї кою сь

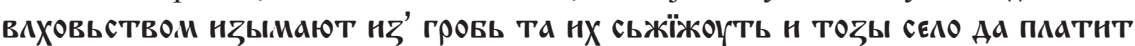

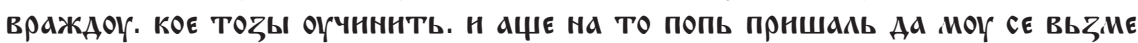
поповьство (Д3, Шишатовачки препис, члан 21). Иако то није експлицитно казано, санкционисани обред из Душановог законика односио се на спаљивање вампира. ${ }^{5}$ Спаљивање је било начин да се тело вампирово потпуно уништи тј. да се униште сви они делови у којима је душа могла остати (упор. пословицу Запекла му се душа у костима). Постојало је, наиме, веровање да ће душа остати везана за тело покојника све док се његово тело не распадне. Такав покојник звао се у српској старини очајник „нерастворено тијело у гробу" (Српски рјечник 1852: I, 667). Стсл. лексема чагатн, чањ : псл. *čajati „чекати, надати се” (ЭССЯ 4: 10-1) претрпела је у српским дијалектима специфичан семантички развитак: „тражити, искати, желети, чекати” $\rightarrow$ „ишчезавати, пропадати” (упор. ...удар нађе искру у камену, / без њега би у кам очајала, Његош, Горски вијенац). Прекид мотивационих веза лексеме очајник могао је бити условљен архаизацијом мотивног глагола *čajati, али и метафоричним развитком њеног значења формираним у контексту табуа.

Траг о старом словенском обреду кремације могла би чувати и рус. лексема клад(б)ище „гробље” (упор. струс. клада 1. „брвно, већи комад дрвета, балван, трупац (на који се што може ставити)”; 2. колода, издубљен комад дрвета у који су стављани мртви”; 3. „погребна ломача, костер тј. купа дрва, грана које се користе за кремацију": творлх이 кладоу вєкнкоу и въдножахоуть н на кмаадог, иртвца сожьжахог (Срезњевски I/2: 1211; изведеница од псл. глагола *klasti, klado „стављати, метати”). ${ }^{6}$ О значењу струс. лексеме клада „обредни огањ” сведочи и назив јужнословенског празника Покладе за који je, поред осталог, карактеристично и паљење обредних, лустративних ватри. Исти мотивациони образац могао се наћи и у номинацији српске лексеме ломача „погребни огањ” тј. првобитно „бреме трња или грања” (Српски рјечник 1852: I, 468) на које се ставља покојник ради кремације.?

2. 3. Гробна хумка, која се и данас насипа над тек сахрањеним покојницима, означава се у неким словенским језицима лексемом могила. У некима од њих она се јавља као основна лексема за дати појам, док у другима она

\footnotetext{
${ }^{5}$ Спаљивање, као основни претхришћански начин на који су Словени своје мртве слали на онај свет, налази се и у основи неких од етимолошких тумачења примарног значења лексеме вампир. У својој студији Димом у небо Александар Лома се позива на етимологијску интерпретацију Т. В. Лукинове која лексему вампир (упор. грч. v-am-piras, pус. ynыр, буг. въпир, чеш., слов. upir, пољ. upiór) доводи у везу са ие. сложеницом (o)n-püros > псл. * qpyrъ „не-спаљен” (упор. срп. пирити, пирјанити), одраженом и у стгрч. придеву á-pyros „без ватре (о обреду)”. Лома каже да се овај начин „упокојења” вампира „...може узети као сећање на паганско доба када је спаљивање било основни погребни обред [...] Вампир би, дакле, био мртвац који је, противно обичају, остао неспаљен, па стога узнемирава своју најближу родбину, која је пре свих била дужна да му омогући прописан погребни обред." (Лома 2004: 54).

${ }^{6}$ Упор. и рус. дијал. приклад „гроб”.

${ }^{7}$ Рјечник ЈАЗУ наводи податак да ова лексема још од XVIII века значи хрпу или гомилу дрва за горење „особито онаку на којој су чељад палили” (РЈАЗУ VI: 43). Упор. и лат. сrето „кремирати, сагорети”, сremia „суха дрва”.
} 
чува своје основно значење „невелико (природно или вештачко) земљано или камено узвишење". 8

Тумачење семантичког развитка псл. лексеме *mogyla од претпостављено примарног „гомила, хумка, узвишење” - из којег се секундарно развило значење „загробна хумка" - није међу етимолозима било општеприхваћено. ${ }^{9}$ Интересантно је становиште В. Орела који полази од општеприхваћене генетске сродности лексема могила и гомила, те узима за примарни облик лексему *gomyla/*gomola/*gomula „гомила, хрпа земље, камена”, а метатезирани облик *mogyla објашњава табуизацијом терминологије погреба (Орел 1984: 301-306). Слабост ове хипотезе налази се у томе да лексема могила, поред обредног, има и опште значење ,хум, брежуљак” у већини сл. језика (ЭССЯ 19: 119). Извесно је да могиле имају претхришћанску старину и да су несумњиво имале посебну улогу у старим словенским жртвеним и погребним култовима, да су служиле као жртвеници или претхришћанске богомоље. Чајкановић на основу израза клетвене или зборне гомиле претпоставља да су на њима вршена и извесна правна поступања (Чајкановић 1994: 166).

У српској погребној терминологији среће се још један термин који се на исти појам односи. То је термин громила - 1. гомила „гомила тј. велико мноштво, хрпа (нпр. камења)”; 2. „могила, праисторијско гробље” (РСАНУ 3: 673). Није сасвим извесно да ли се у гласовном лику ове лексеме крије контаминација са семантички сродним лексемама попут громада, грумен (громиле су карактеристичне по насипању грумењем већег или мањег камења) или је у питању једна од лексема која у хронолошки дубљим слојевима чува старе културне трагове.

У раду Заметки по этимологии и сравнительной грамматике О. Трубачев на основу црквенословенског облика громы (акуз. множ.), посведоченог у речнику Срезњевског (Срезњевски 1989: I, 597) ${ }^{10}$, претпоставља особено прасловенску иновацију * gromъ „жртва”, објаснивши тај облик као реликтни нетематски трпни партицип садашњег времена изведен од псл. глсголског корена *gr- (са редукованим степеном коренског вокала, од индоевропског

\footnotetext{
${ }^{8}$ Упор. псл. *mogyla, цсл. могыма tumulus (Миклошич, 378), срп./хрв. могила 1. „невелико земљано (природно или вештачко) узвишење”; „камена или земљана хумка”; „велика хрпа камења која је служила као знак међе или ограда" (нпр. у повељама српских владара, Даничић II: 84-85); 2. „старинска, преисторијска гробница с великим насипом, тумул” (РСАНУ 12: 769-770); буг. могила, дијал. гомила „хум, брешчић”; словен. gomila 1. „земљани брежуљак”; 2. „могилни брежуљак”; стпољ. mogiła 1. „природна или вештачка груда земље (као гранично обележје)”; 2. „курбан, гробна хумка”; 3. „камени ступ подигнут у спомен на владаоца или бога”; чеш./слов. mohyla „високи земљани или камени насути хум над гробом”; рус. могила, укр. могила, блр. магіла - у којима је преовлађујуће значење „курган, гробна хумка”, али се спорадично среће и прво значење тј. „невелико земљано (природно или вештачко) узвишење”, ЭССЯ 19: 115-117).

${ }^{9}$ Једна од хипотеза о семантичкој еволуцији ове лексема полазила је од очигледног формалног поклапања ове лексеме са алб. mágulë „хумка, брег”, gamúlë „гомила земље или траве” и рум. măgură „исто” и тумачила је као позајмљеницу из ових језика (ову хипотезу изнео је још Х. Барић; супротно сматра Фасмер II: 534 наглашавајући њено општесловенско распростирање). Други истраживачи сматрају је позајмљеницом из неких других језика - скитског језика (Coбољевски), келтског (Шахматов) итд. О томе више в. ЭССЯ 19: 118.

${ }^{10}$ У другом списку споменика Срезњевски бележи трєвы „жртве”; упор. и грч. паралелу $\theta 0 ́ \mu \alpha \tau \alpha$ коју Срезњевски такође наводи.
} 
прајезичког корена * $g^{u} e r-$ „ждерати, гутати”) (Трубачев 1972: 9). ${ }^{11}$ У исто етимолошко гнездо, ако прихватимо Трубачевљево тумачење, спадале би и неке пољске, чешке, украјинске и белоруске лексеме (упор. пољ. gromnica, чеш. hromnice, hromice, укр. грімниця, громниця, блр. грамніца) са значењем: 1. „празник Сретење (2/15. фебруара)”; 2. „свећа која се освештава у цркви као апотропеј од муња”. Свеће су биле познате магијској словенској пракси и палиле су се у време првог изгона стоке, у време жетве заједно са хлебом, просфором итд. Њихово паљење у време непогоде, да би штитиле од муња, чест је случај профилактичке магије. Значење ових лексема се, по мишљењу А. Журављева, народним (лажним) етимологисањем повезивало са хомонимичном речју * groms „гром”. Узимајући у обзир претходно изнето Трубачевљево етимолошко тумачење, овај аутор сматра да се у основи наведених словенских лексема налази појам „жртвеноприношења” (и даље назива празника), „жртвеног дара”. Сам словенски глагол са кореном * $g r$ - није посведочен, али се може претпоставити да је изгубљен под утицајем конкурентног синонимичног облика са кореном *žbr- (Журављев 2010: 11-12).

Према овим етимолошко-етнографским сведочењима могли бисмо претпоставити да су громиле првобитно биле нека врста жртвеника који су били у вези са погребном церемонијалном праксом. ${ }^{12}$ Временом су у језичком знању српских говорника могли бити запретени ови стари религиозно-митолошки слојеви, те лексема громила данас има исто значење као и могила, тј. 1. „велико мноштво, хрпа (нпр. камења)”; 2. „могила, праисторијско гробље”. Иако коначни етимолошки суд о настанку напред наведених лексема није донет, њихови варијантни фонетски ликови ( *gomyla/*gomola/*gomula, громила, могила) могу сведочити у прилог Ореловом тумачењу развитка метатезираног лика могила, односно о томе да је табуом условљена забрана употребе основног термина „гроб, гробна хумка” водила настанку низа супституената чији нерегуларни фонетизам може бити једном од последица функционисања табуа на језичком плану.

Лексема рака (упор. стсл. рака „гробна јама”, буг. рака „сандук са моштима”, словен. raka „гробница”) је, по свему судећи, латинског порекла (: лат. $a r k a$ „сандук, ковчег” од аrсеô „закључавам”). Она је посредством готског била пренета у словенске језике (Фасмер III: 437). Изворно значење ове лексеме носи данас у српском језику назив предмета у који се ставља мртви пре инхумације (,сандук, ковчег”), док је сам латински по пореклу термин, метатезом транспонован у лексему рака, добио значење „гробна јама”. Арка

\footnotetext{
${ }^{11}$ Од овог прајезичког корена неки етимолози изводе и прасловенску реч *žrb-tva (коренови се разликују само по аблаутном степену коренског вокала: *gr-/*ger- > *žer- /*žbr-). В. Н. Топоров је псл. *žerti, *žbrQ „приносити жртву, жртвовати” повезивао са псл. глаголом *žbrati ,jести, пити” (упор. рус. нажраться, чеш. ožrati se „опити се, напити се”) подразумевајући мотивациони модел који упућује на постојање ритуалне трпезе која је у жртвеној церемонији следовала за чином приношења жртве (Варбот 2012: 295-296).

${ }^{12}$ Археолошка евиденција показује да неке раносредњовековне српске громиле не чувају пепео (нити друге остатке покојника) и да вероватно представљају неку врсту култног места (обредног станишта) на којем су вршени погребни церемонијали. У њима су нађене спаљене животињске кости, уломци грнчарије (погребна гозба?), остаци некаквих грађевина, огњишта, предмети који су припадали умрлима и сл. (Јанковић 1998: 117-120).
} 
представља једну из реда хришћанских „културних речи”, јер је према Библији то био назив лађе у којој се Ноје спасао од потопа, а такође се јавља и у називу Ковечега завета тј. највеће јеврејске светиње у којем се налазио текст Мојсијевих Десет заповести. Ови културно конотирани слојеви значења чувају се у примеру наведеном из бугарског језика, док је у српском њено сакрално значење данас избледело, могуће и због споменуте метатезе која је прекинула везу са изворном лексемом и културном сфером њеног значења. Извесно је да је табузација појма „гробна јама” условила метафорични пренос основног значења ове лексеме, а да је табу могао утицао и на само позајмљивање, сведочи, на пример, источнословенски дијал. погребни термин труна/трумна/трува ,гроб” позајмљен посредством пољског језика од нем. Truhe (Седакова 2004: 233), као и бројни савремени примери супституисања табуиране лексеме неком позајмљеницом (упор. нпр. спалити : кремирати). Табуисањем основног појма „мртвачки сандук, ковчег” могло би се објаснити и пренесено значење лексеме лијес (упор. стсл. $\mathbf{s} \mathbf{c} ъ$ „дрвеће, шума”).

Лексеме (вечна, ледена) кућа, двор, дом, двор-самотвор које у значењу „гроб” срећемо у општеупотребном и фолклорном контексту (упор. текст тужбалице: С јадом сам ти на двор дошла, / јад је мене! Да обидем бона тебе! / боре доме ${ }^{13}$ ! И да питам јадна тебе, / много јадна! С чим си ми се ти понио, / добар доме! Е си дворе саградио, / граде доме! / Нове дворе самотворе, / само јадна!) - представљају прозирне метафоре, општесловенског распростирања (упор. нпр. рус. дијал. домовина, домовіна, домик, домовка, домовище; буг. къща; укр. нова хата, гарна хата вічна и сл., Седакова 2004: 139), настале у координатама семиотичких опозиција живот/смрт, при чему се гроб перципирао као покојникова „вечна кућа”. У основи њихове номинације стоји метафорична концептуализација, мотивисана табуом. Исто се може рећи и за рус. дијал. лексему погост „гробље”, која се по Зељењину доводи у везу са обредом погребних гозби (од псл. *gostb ${ }^{14}, *$ gostbba), као и за лексеме жальник, жаль којима су најчешће називана паганска гробља или гробља тзв. „заложних" тј. нечистих покојника (Зељењин 1929: 150).

2.4. У претходном излагању анализирани су само неки од основних појмова, односно лексема које припадају погребном обредном комплексу, односно језику културе датог обреда. Шире засновано истраживање ове лексике, са укључивањем њених општесловенских паралела, показало би да је исти метафорични концепт скривања, тајности присутан и у означавању неких других аспеката погребног обреда, као и да цео погребни обред представља супституцију реалне чињенице смрти - смрћу симболичком, ритуалном.

${ }^{13}$ Наведени израз могао би бити у вези са метафором дрво : смрт везаној за посредничку коју је дрво имало у погребним обредима претхришћанске старине (душа мртвих кроз дрвеће иде на онај свет; упор. рус. дијал. дерево, деревище, колода „гроб”, фразем дубу дать „умрети”, дуб-вертодуб „смрт” (у загонеткама) и сл., Седакова 2004: 138; упор. и ...из Омера зелен бор никао, / Из Мејриме зелена борика..., нар. песма Омер и Мерима). Веровање да се душа после смрти склања у гробно стабло (Чајкановић 1973: 6) довело је до погребне праксе сађења биљки или дрвета на гробној хумци.

${ }^{14}$ Упор. и рус. дијал. гостенин „умрли”, гостьбище „гробље”, Седакова 2004: 216. 
Забрана употребе неке речи која се односи на појам „СМРТИ” била је првенстено условљена културним, религиозно-митолошким факторима и доводила до стварања њеног еуфемистичког еквивалента који је метафорично концептуализован и у чијим се дубљим семантичким слојевима налазе трагови архаичног митопоетског мишљења.

Неке од разматраних лексема настале су на подлози метафора у којима се скривени објекат открива у конкретним, очигледним представама које су способне да стичу знаковна, симболичка својства задржавајући притом везу са својим конкретним обележјима (скончати, преставити се, уснути, упокојити се, заклопити очи, погрети, укоп, могила, громила, ломача, вечна

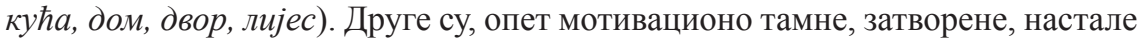
у сфери религиозно-митолошких архаичних представа и у њима симболично значење преовладава над конкретно-предметним (смрт, гинути, сахранити, очајник, рака и сл.). У овим метафорама поређени појмови и њихова значења сливени су у нераскидиво јединство, те их можемо разоткрити само у систему семиотичког језика културе у којој су поникле и осветлити методама етимолошке и упоредно-историјске језичке анализе.

\section{ЛИТЕРАТУРА}

Бандић 1975: Д. Бандић, „Трагови табуа у самртном ритуалу Срба”, Гласник Етнографског института, књ. 23 (1974), Београд, 95-116.

Варбот 2012: Ж. Ж. Варбот, Исследования по русской и славянской этимологии, Москва - Санкт-Петербург: Нестор - История, 295-296.

Вучковић 2014: Марија Вучковић, Концепт „ЛОШЕ СМРТИ”, Етноантрополошки проблеми, год. 9, св. 2, 513-537.

ДЗ: Законик ицара Стефана Душана, књ. ІІІ, Београд: САНУ, 1997.

Ђорђевић 1937: Тихомир Ђорђевић, „Неколики самртни обичаји у Јужних Словена", Годишњица Николе Чупића, 46, 75-103.

Ђорђевић 1940: Тихомир Ђорђевић, „Неколики самртни обичаји у Јужних Словена", Годиињица Николе Чупића, 49, 70-84.

Ђорђевић 1941: Тихомир Ђорђевић, „Неколики самртни обичаји у Јужних Словена", Годишњииа Николе Чупића, 50, 144-176.

Журављев 2010: А. Ф. Журавлев, Интуиция этимолога, Этимология 20062008, Москва (2010), 3-24.

Зељењин 1929: Д. К. Зеленин, Табу слов у народов восточной Европы и северной Азии, часть II: Запреты в домашней жизни, Сборник музея антропологии и этнографии, T. IX, Москва: Академия наук.

Зечевић 1982: Слободан Зечевић, Култ мртвих код Срба, Београд: Вук Караџић, Етнографски музеј. 
Јанковић 1998: Ђорђе Јанковић, Српске громиле, Београд: НИП Књижевна реч.

Лома 2004: Александар Лома, Димом у небо. „Обред спаљивања мртвих у старим и традиционалним културама. Његово осмишљење у есхатолошким представама индоевропских народа, са посебним освртом на паганске Словене", Кодови словенских култура, 9, 7-64.

Орел 1984: В. Э. Орел, Слав. *mogyla, ОЛА 1981, Москва (1984), 301-306.

PJA3У: Rječnik hrvatskoga ili srpskoga jezika, Zagreb: Jugoslavenska akademija znanosti i umjetnosti, 1880-1882/1975-1976.

РСАНУ: Речник српскохрватског књижевног и народног језика, том 1-, Београд: САНУ, 1959-.

Седакова 2004: О. А. Седакова, Поэтика обряда. Погребальная обрядность восточных и южсых славян, Москва: Индрик.

Седов 1990: В. В. Седов, Погребальный обряд славян в начале средневековья, Исследования в области балто-славянской духовной культуры: Погребальный обряд, Москва: Наука, 170-182.

Срезњевски 1989: И. И. Срезневский, Словарь древнерусского языка, Репринтное издание, том I, Москва: „Книга”.

Српски рјечник 1852: Вук Стефановић Караџић, Српски рјечник (1852) I-II, Сабрана дела Вука Карџића, књ. 11, Београд: Просвета, 1986.

CC: Старославянский словарь, по рукописям X-XI веков, Москва: Русский язык, 1994.

Толстој С. 2009: С. Толстая, 'Коромит' и 'хоронит' (к семантической реконструкции славянской погребальной лексики), Studia etymologica Brunensia 6, Praha: Nakladateství Lidové noviny, 341-355.

Топоров 1987: В. Н. Топоров, Заметки по похороной обрядности, Балтославянские исследования 1985, Москва, 10-52.

Трубачев 1972: О. Н. Трубачев, Заметки по этимологии и сравнительной грамматике, Этимология 1970, Москва (1972), 9-10.

Фасмер 1986/1987: Макс Фасмер, Этимологический словарь русского языка $I-I V$, Москва: Прогресс.

Чајкановић 1973: В. Чајкановић, Мит и религија у Срба. Изабране студије. Београд: СКЗ.

Чајкановић 1994: В. Чајкановић, Сабрана дела из српске религије и митологије, књ. V, Београд: СКЗ - БИГЗ - Просвета - Партенон.

ЭССЯ: Этимологический словарь славянских языков [ред. О. Н. Трубачев], том 1-, Москва: Наука, 1974-. 
Snežana P. Vučković

TABOO WORDS IN THE DISCOURSE OF BURIAL RITUALS IN SERBIAN

Summary

This paper presents a study of lexemes belonging to the semantic field of burial rituals in Serbian. In an effort to identify some basic nominalization patterns in the process of their formal and semantic formation such items are deconstructed from the motivational aspect. We try to highlight the role of taboos in the process of metaphorical conceptualization of such lexemes. They clearly represent a linguistic manifestation of some archaic etno-cultural elements which are therefore presented in this paper, too. 